\title{
VOLTAMMETRIC BEHAVIOURS OF Zn(II) AND Ni(II) COMPLEXES WITH ACID RED 1 AT MERCURY ELECTRODE
}

\author{
ENDER BIÇER*, CABIR ARAT \\ Department of Chemistry, Faculty of Arts and Sciences, Ondokuz Mayls University, 55139 Kurupelit-Samsun, TURKEY
}

(Received: April 28, 2008 -Accepted: September 15, 2008)

\begin{abstract}
The interaction of Acid Red 1 (AR 1) with $\mathrm{Zn}$ (II) and $\mathrm{Ni}(\mathrm{II})$ ions in $\mathrm{NH}_{3} / \mathrm{NH}_{4} \mathrm{Cl}$ buffer solution $(\mathrm{pH}=9.20$ ) was investigated for the first time by squarewave and cyclic voltammetry techniques. The voltammetric behaviours of the formed complexes were discussed. From the obtained results, their overall stability constants were calculated by using different equations, suitable to the property of the complexation process. The reduction of $\mathrm{Ni}$ (II)-AR 1 complex was shown at more positive potential $(-0.768 \mathrm{~V})$ than that $(-0.910 \mathrm{~V})$ of free $\mathrm{Ni}(\mathrm{II})$ in the absence of AR 1 . The logarithm of overall stability constant (log $\left.\beta_{1.2}\right)$ and stoichiometry of the complexation of $\mathrm{Ni}(\mathrm{II})$ with AR 1 were determined to be 9.30 and 1:2 (metal:ligand), respectively. However, the composition of the Zn(II)-AR 1 complex is $1: 1$, and the logarithm of its stability constant $\left(\log \beta_{1 \cdot 1}\right)$ was determined as 3.66 by the direct monitoring of the current of free zinc(II).
\end{abstract}

Key words: Zinc, Nickel, Acid Red 1, Voltammetry.

\section{INTRODUCTION}

Since the metal ion complexes play an important role in life science, pharmacology, complexometric titration, colorimetric analysis, precipitation and solvent extraction, the determination of the stability constants of metal ion complexes with different ligands is very important ${ }^{1}$. Azo dyes are a very important class of organic compounds receiving attention in the scientific literature. Recently, azo metal chelates have drawn the attention of some research due to their excellence in sensitivity and stability as optical recording medium $^{2,3}$. Moreover, the complexes of some azo dyes with metal ions, such as $\mathrm{Ni}(\mathrm{II}), \mathrm{Cu}(\mathrm{II}), \mathrm{Zn}(\mathrm{II})$, and $\mathrm{Co}(\mathrm{II})$ have been recently investigated as recording materials for DVD-R (Digital Versatile Disc-Recordable) ${ }^{4}$.

Among the electrochemical techniques, voltammetry has been widely used to study the interactions between metal ions and ligands ${ }^{5-11}$. The voltammetric and polarographic studies on the metal complexes of the some azo-dye ligands were done in the literature ${ }^{12-17}$.

AR 1 (also called azophloxine, see Scheme 1) is an azo dye, used in light and fluorescence microscopy as a real acid counterstain ${ }^{18}$. In addition, AR 1 is a reactive azo dye belonging to the largest class of dyes commonly employed in textile industry ${ }^{19}$. No information is available about the voltammetric behaviour of $\mathrm{Ni}(\mathrm{II})$ and $\mathrm{Zn}(\mathrm{II})$ complexes with $\mathrm{AR} 1$. In the present paper, we report on the determination of the stability constants and stoichiometries of these dipositive metal ions with AR 1 by using square-wave voltammetry and cyclic voltammetry.

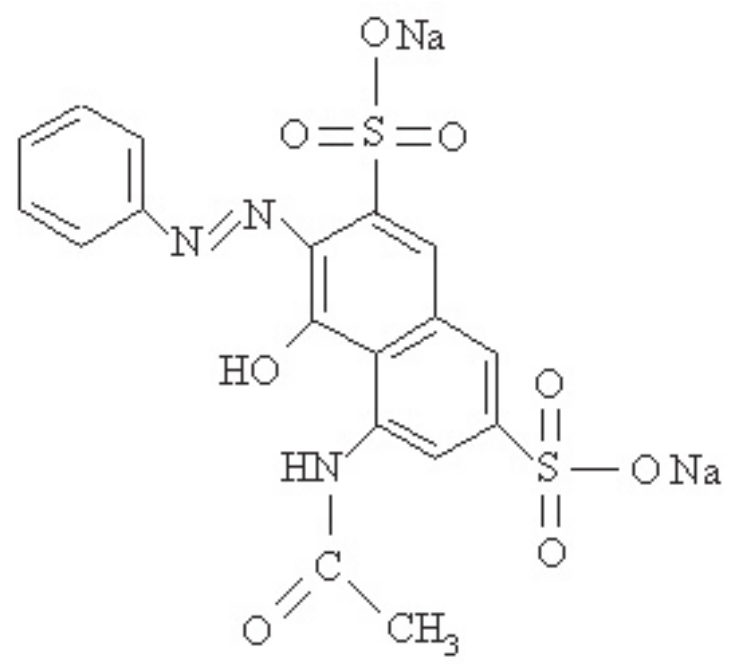

Scheme 1. The molecular structure of AR 1 sodium salt.

\section{EXPERIMENTAL}

\section{Reagents}

AR 1 sodium salt was purchased from MP Biomedicals, LLC and was used as received. $\mathrm{Ni}\left(\mathrm{ClO}_{4}\right)_{2} 6 \mathrm{H}_{2} \mathrm{O}$ and $\mathrm{Zn}\left(\mathrm{ClO}_{4}\right)_{2} 6 \mathrm{H}_{2} \mathrm{O}$ were purchased from Alfa Easer and Aldrich, respectively. All the chemicals used were of analyticalreagent grade and used without further purification. The stock solutions of AR $1, \mathrm{Ni}(\mathrm{II})$ and $\mathrm{Zn}$ (II) were prepared by directly dissolving them in deionized and triply distilled water.

\section{Apparatus}

Voltammetric measurements were carried out on a EG\&G PAR Model 384B Polarographic Analyzer connected to a EG\&G PARC Model 303A SMDE electrochemical cell composed to a hanging mercury drop electrode (working electrode), an $\mathrm{Ag}|\mathrm{AgCl}| \mathrm{KCl}_{\text {sat }}$ electrode (reference electrode) and a platinum electrode (auxiliary electrode). Voltammograms were recorded with DMP-40 XY Plotter (Houston Instruments Inc.).

Electronic spectra were taken by a Unicam V2-100 UV-Vis spectrophotometer in the $800-200 \mathrm{~nm}$ range using a $1 \mathrm{~cm}$ passlength quartz cell.

\section{Procedure}

For the complexation, the best results with respect to signal magnitude and reproducibility were obtained in $\mathrm{NH}_{3} / \mathrm{NH}_{4} \mathrm{Cl}$ buffer solution $(\mathrm{pH}=9.20)$. Therefore, this medium was employed as the supporting electrolyte throughout the study. The voltammograms of $\mathrm{Zn}(\mathrm{II})$ and $\mathrm{Ni}(\mathrm{II})$ at $\mathrm{NH}_{3} / \mathrm{NH}_{4} \mathrm{Cl}$ buffer solution $(\mathrm{pH}=9.20)$ were recorded to obtain the peak current and the peak potential values for the reduction process of these metal ions in the absence of AR 1. On the other hand, the voltammogram of AR 1 in the absence of the metal(II) ions was also obtained at the same supporting electrolyte. After that, the addition of AR 1 to the voltammetric cell, containing metal(II) ions and vice versa were carried out. After each addition, voltammograms were recorded to obtain the peak current value and the peak potential of free or bound metal(II) in the presence of AR 1 .

Apart from the supporting electrolyte, other experimental variables (scan rate, frequency, pulse height, etc.) affecting the voltammetric response were evaluated and optimized. These instrumental parameters were also held constant throughout this research. The square-wave voltammograms were obtained by using equilibrium time of $5 \mathrm{~s}$; scan rate of $200 \mathrm{mVs}^{-1}$; scan increment of 2 $\mathrm{mV}$; frequency of $100 \mathrm{~Hz}$; pulse height of $0.020 \mathrm{~V}$; drop size, medium (unless stated otherwise). The experimental conditions for cyclic voltammetry were: scan rate, $500 \mathrm{mV} \mathrm{s}^{-1}$; scan increment, $2 \mathrm{mV}$; equilibrium time, $5 \mathrm{~s}$; drop size, medium.

Solutions were deaerated for about $5 \mathrm{~min}$ with pure nitrogen gas before starting the electrochemical experiments. Nitrogen gas was passed over the solutions during the experiments. Each measurement was performed with a fresh mercury drop at room temperature.

The spectra of free AR 1, metal(II) solutions and also mixtures of metal(II) with $\mathrm{AR} 1$ at $\mathrm{NH}_{3} / \mathrm{NH}_{4} \mathrm{Cl}$ buffer solution $(\mathrm{pH}=9.20)$ were recorded. The changes in the spectra were followed. 


\section{RESULTS AND DISCUSSION}

AR 1 in the presence of nickel(II) ions

At $\mathrm{NH}_{3} / \mathrm{NH}_{4} \mathrm{Cl}$ buffer solution $\mathrm{pH} 9.20$, the square-wave voltammogram of $4.76 \times 10^{-5} \mathrm{M}$ Ni(II) ions exhibited a cathodic peak at $-0.910 \mathrm{~V}$ (Fig. 1). In the literature ${ }^{20}$, it was reported that $\left[\mathrm{Ni}\left(\mathrm{NH}_{3}\right)_{6}{ }^{2+}\right.$ reduced at half-wave potential of $-1.09 \mathrm{~V}$ (versus Saturated Calomel Electrode) with a cathodic reaction of two-electrons $(2 \rightarrow 0)$. Therefore, the peak at $-0.910 \mathrm{~V}$ can be inferred from the reduction of $\left[\mathrm{Ni}\left(\mathrm{NH}_{3}\right)_{6}\right]^{2+}$ ions on mercury electrode to the amalgam.

$4.76 \times 10^{-5} \mathrm{M}$ AR 1 exhibits two peaks at $-0.478 \mathrm{~V}$ and $-0.676 \mathrm{~V}$ in $\mathrm{NH}_{3}$ / $\mathrm{NH}_{4} \mathrm{Cl}$ buffer solution $\mathrm{pH} 9.20$ (Fig. 2). These peaks have previously been characterized $^{21}$. The first can be sourced from the adsorption phenomena of AR 1 while the main (second) reduction peak may be attributed to the reduction of $-\mathrm{N}=\mathrm{N}$ - group to the amines with consuming of four electrons ${ }^{21}$. The potential and current values of these peaks also depend on the experimental conditions.

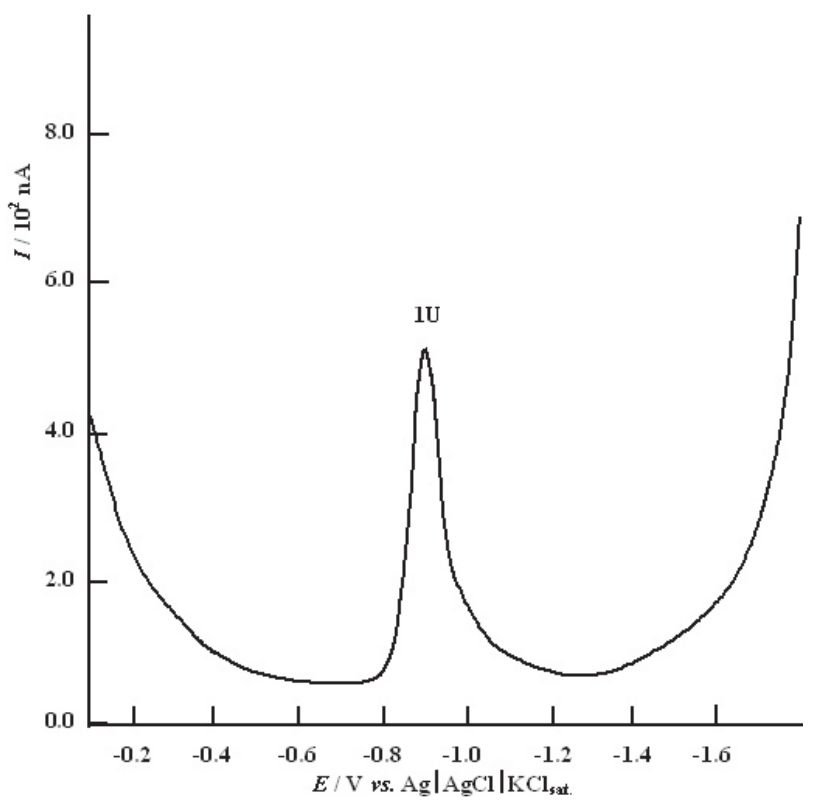

Fig. 1. Square-wave voltammogram of $4.76 \times 10^{-5} \mathrm{M} \mathrm{Ni}$ (II) solution at $\mathrm{NH}_{3}$ / $\mathrm{NH} \mathrm{Cl}$ buffer solution $\mathrm{pH} 9.20$. 1U, the reduction of free $\mathrm{Ni}(\mathrm{II})$. Experimental conditions: scan rate, $200 \mathrm{mV} \mathrm{s}^{-1}$; scan increment, $2 \mathrm{mV}$; frequency, $100 \mathrm{~Hz}$; pulse height, $0.020 \mathrm{~V}$; equilibrium time, $5 \mathrm{~s}$; drop size, medium.

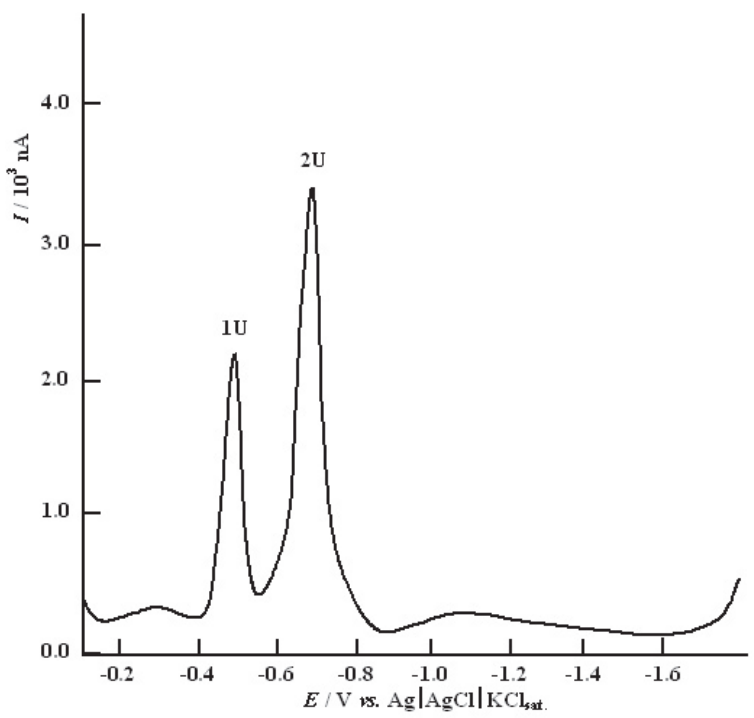

Fig. 2. Square-wave voltammogram of $4.76 \times 10^{-5} \mathrm{M}$ AR 1 solution at $\mathrm{NH}_{3} / \mathrm{NH}_{4} \mathrm{Cl}$ buffer solution $\mathrm{pH} 9.20$. 1U , the adsorption peak of AR $1 ; \mathbf{2} \mathbf{U}$, the reduction of $-\mathrm{N}=\mathrm{N}-$ group of $\mathrm{AR}$ 1. Other conditions as in Fig. 1.
Gradually increasing AR 1 concentration in the cell containing $4.76 \times 10^{-5}$ $\mathrm{M}$ nickel(II) results in both a decrease in the peak corresponding to the reduction of $\left[\mathrm{Ni}_{(}\left(\mathrm{NH}_{3}\right)_{6}\right]^{2+}$ and the appearance of a new irreversible peak at $-0.768 \mathrm{~V}$ (Figs. 3 and 4 ). The reduction potential of this new peak lies at more positive potential compared to that of $\left[\mathrm{Ni}\left(\mathrm{NH}_{3}\right)_{6}\right]^{2+}\left(E_{\mathrm{p}}=-0.910 \mathrm{~V}\right)$. The similar results were also obtained when $\mathrm{Ni}(\mathrm{II})$ ions were added to AR 1 solution in the ammonium buffer system. With increasing $\mathrm{Ni}(\mathrm{II})$ concentration, additional peak appears at $-0.768 \mathrm{~V}$ (Fig. 5). The decrease of the peak of free AR 1 in the presence of $\mathrm{Ni}$ (II) ions confirms the interaction between them. The peak at $-0.768 \mathrm{~V}$ can be due to the reduction of $\mathrm{AR} 1$ complexed with $\mathrm{Ni}$ (II) ion according to following equilibrium:
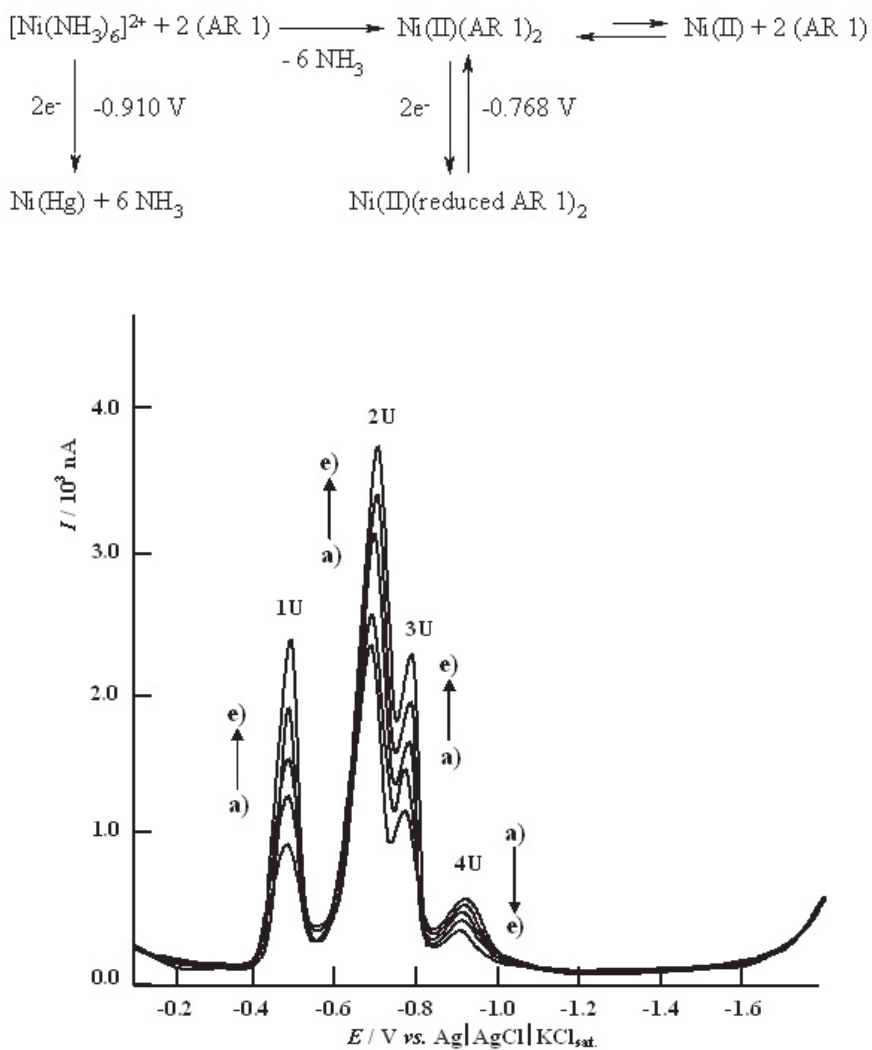

Fig. 3. Square-wave voltammograms of $4.76 \times 10^{-5} \mathrm{M} \mathrm{Ni}(\mathrm{II})$ solution containing a) $2.77 \times 10^{-5} \mathrm{M}$; b) $3.67 \times 10^{-5} \mathrm{M}$; c) $4.54 \times 10^{-5} \mathrm{M}$; d) $6.25 \times 10^{-5} \mathrm{M}$; e) $7.90 \times 10^{-5} \mathrm{M} \mathrm{AR} 1$ solution at $\mathrm{NH}_{3} / \mathrm{NH}_{4} \mathrm{Cl}$ buffer solution $\mathrm{pH} 9.20$. $\mathbf{1} \mathbf{U}$, the adsorption peak of $A R 1 ; \mathbf{2} \mathbf{U}$, the reduction of $-\mathrm{N}=\mathrm{N}-$ group of $\mathrm{AR} 1 ; \mathbf{3} \mathbf{U}$, the reduction of $\mathrm{Ni}(\mathrm{II})-(\mathrm{AR} 1)_{2}$ complex; $\mathbf{4} \mathbf{U}$, the reduction of free $\mathrm{Ni}(\mathrm{II})$. Other conditions as in Fig. 1. 


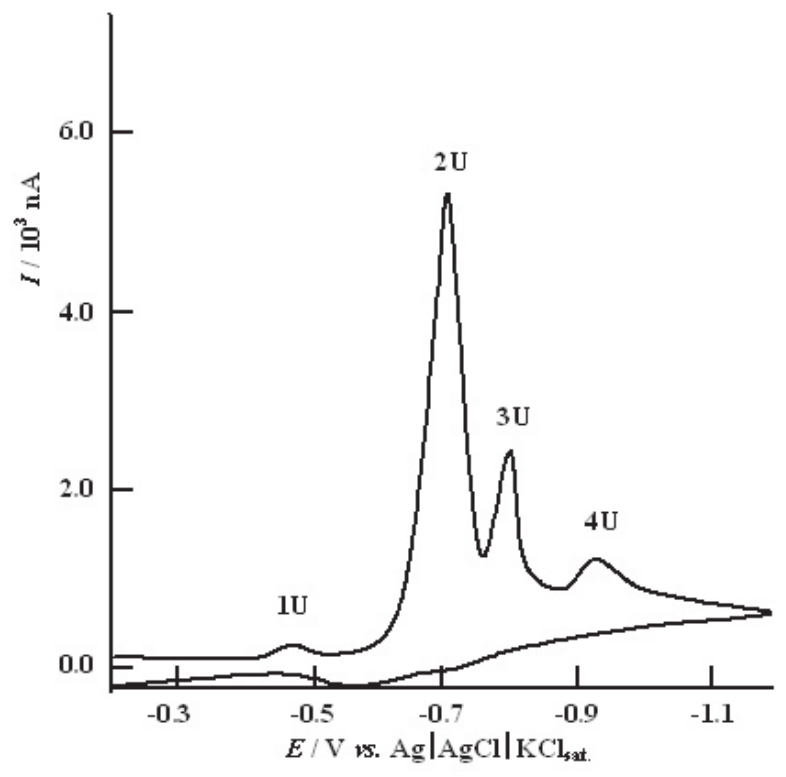

Fig. 4. Cyclic voltammogram of $4.76 \times 10^{-5} \mathrm{M} \mathrm{Ni}(\mathrm{II})$ solution containing $5.40 \times 10^{-5} \mathrm{M}$ AR 1 at $\mathrm{NH}_{3} / \mathrm{NH}_{4} \mathrm{Cl}$ buffer solution $\mathrm{pH}$ 9.20. Experimental conditions: scan rate, $500 \mathrm{mV} \mathrm{s}^{-1}$; scan increment, $2 \mathrm{mV}$; equilibrium time, 5 s; drop size, medium.

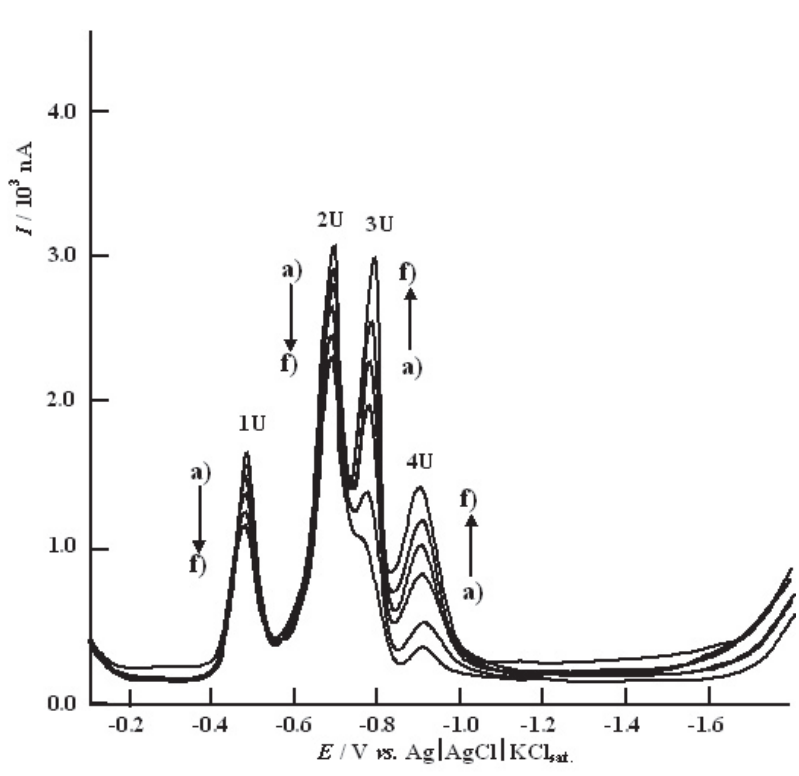

Fig. 5. Square-wave voltammograms of $4.76 \times 10^{-5} \mathrm{M}$ AR 1 solution containing a) $1.87 \times 10^{-5} \mathrm{M}$; b) $3.67 \times 10^{-5} \mathrm{M}$; c) $5.40 \times 10^{-5} \mathrm{M}$; d) $7.08 \times 10^{-5} \mathrm{M}$; e) $8.70 \times 10^{-5} \mathrm{M}$; f) $1.03 \times 10^{-4} \mathrm{M} \mathrm{Ni}(\mathrm{II})$ solution at $\mathrm{NH}_{3} / \mathrm{NH}_{4} \mathrm{Cl}$ buffer solution $\mathrm{pH} 9.20$. 1U , the adsorption peak of $\mathrm{AR} 1 ; \mathbf{2} \mathbf{U}$, the reduction of $-\mathrm{N}=\mathrm{N}-$ group of AR $1 ; \mathbf{3} \mathbf{U}$, the reduction of $\mathrm{Ni}(\mathrm{II})$-(AR 1$)_{2}$ complex; $\mathbf{4} \mathbf{U}$, the reduction of free $\mathrm{Ni}(\mathrm{II})$. Other conditions as in Fig. 1.

In the presence of complexing agents, the reduction of a metal ion occurs at more negative potentials. This may be attributed to the more bulky complexed ion requiring more energy in order to undergo the reduction process at mercury electrode. However, there are cases where the reduction potential of a metal ion shifts to more positive values with increasing ligand concentration. In such cases it is evident that reduction of the complexed ions occurs more readily than that of the aqua ions. Such behavior was shown by nickel (II) ${ }^{22}$. Ni(II) complexes with nitrogen coordinated-ligands like pyrazole, $\mathrm{NH}_{3}$, pyridine or aminosugars are reduced at more positive potentials than the aquaion ${ }^{22-30}$.

Since the reduction potential $(-0.768 \mathrm{~V})$ of AR 1 complex with $\mathrm{Ni}(\mathrm{II})$ are close to that $(-0.842 \mathrm{~V})$ of $\mathrm{Ni}(\mathrm{II})-$ Solochrome violet RS complex ${ }^{12}$. Since the
AR 1 can be reducible in the $\mathrm{Ni}(\mathrm{II})(\mathrm{AR} 1)_{2}$ complex, for the reduction of such a metal complex where the ligand is reducible, two possible cases are present ${ }^{14}$ : 1) The complex is reduced while the metal ion remains complexed with the reduced form of the ligand. 2) The complex dissociates at the electrode surface prior to reduction and the free ligand is reduced. According to the experimental results, the former case is more suitable for the $\mathrm{Ni}(\mathrm{II})(\mathrm{AR} 1)_{2}$ complex.

In order to obtain the coordination number $(m)$ and the stability constant $(\beta)$ of the complex, the following equation ${ }^{31}$ can be used:

$$
1 / I_{p}=1 / I_{p, \max }+1 /\left\{\beta I_{p \max }[\mathrm{AR} 1]^{m}\right\}
$$

where $I_{p}$ stands for the peak current of $\mathrm{Ni}(\mathrm{II})-\mathrm{AR} 1$ complex, $I_{p, \max }$ is the peak current when all the metal ion forms the complex and [AR 1] is the concentration of Acid Red 1 . The curve of $-\log \left[I_{p} /\left(I_{p, \max }-I_{p}\right)\right]$ versus $-\log [\mathrm{AR}$ 1] is linear with the slope of $m$ (Fig. 6). The results of $m=2$ and $\log \beta=9.30$ were obtained, which means that only $\mathrm{Ni}(\mathrm{II})(\mathrm{AR} 1)_{2}$ complex is formed. It was reported that stability constant of the highest complex of $\mathrm{Ni}(\mathrm{II})$ with ammonia $\left(\beta_{6}\right)$ is $8.74^{22,32}$. Since the overall stability constant of $\mathrm{Ni}(\mathrm{II})(\mathrm{AR} 1)_{2}$ complex is bigger than that of $\mathrm{Ni}(\mathrm{II})\left(\mathrm{NH}_{3}\right)_{6}$ complex, $\mathrm{Ni}(\mathrm{II})(\mathrm{AR} 1)_{2}$ complex is more stable than $\mathrm{Ni}(\mathrm{II})\left(\mathrm{NH}_{3}\right)_{6}$ complex. Acid Red 1 can coordinate with metal ions through its azo-nitrogen, phenolic oxygen and amide-oxygen sites (Scheme 1). The formation of $\mathrm{Ni}(\mathrm{II})(\mathrm{AR} 1)_{2}$ complex in $\mathrm{NH}_{3} / \mathrm{NH}_{4} \mathrm{Cl}$ buffer solution $\mathrm{pH} 9.20$ probably occurs via the successive replacement of AR 1 ligands with ammonia molecules. The structures of $\mathrm{Ni}$ (II) complex, including coordination of the uncharged amide oxygen to the metal ion were previously reported ${ }^{33}$. As a similar form to the binding of $\mathrm{Ni}(\mathrm{II})$ ions with some azo-compounds $\mathrm{s}^{15,34}$, the structure of the complex of $\mathrm{Ni}(\mathrm{II})$ with AR 1 was proposed as shown in Scheme 2 .

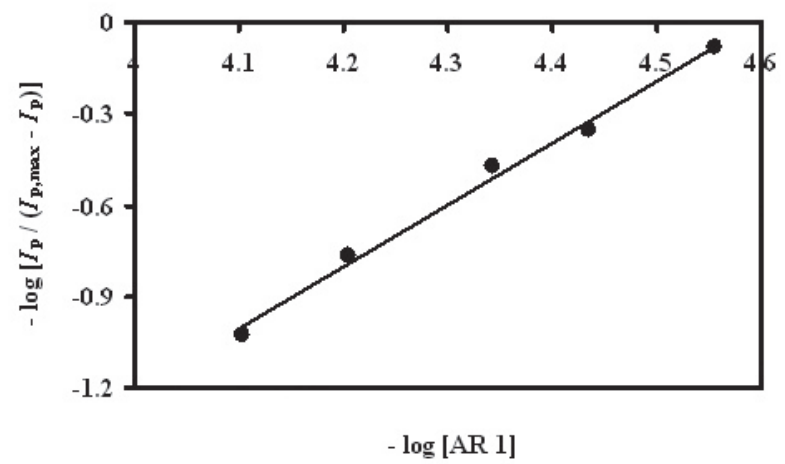

Fig. 6. The plot of $-\log \left[I_{p} /\left(I_{p \max }-I_{p}\right)\right]$ versus $-\log [\mathrm{AR} 1]$ at $\mathrm{NH}_{3} / \mathrm{NH}_{4} \mathrm{Cl}$ buffer solution $\mathrm{pH} 9.20$.

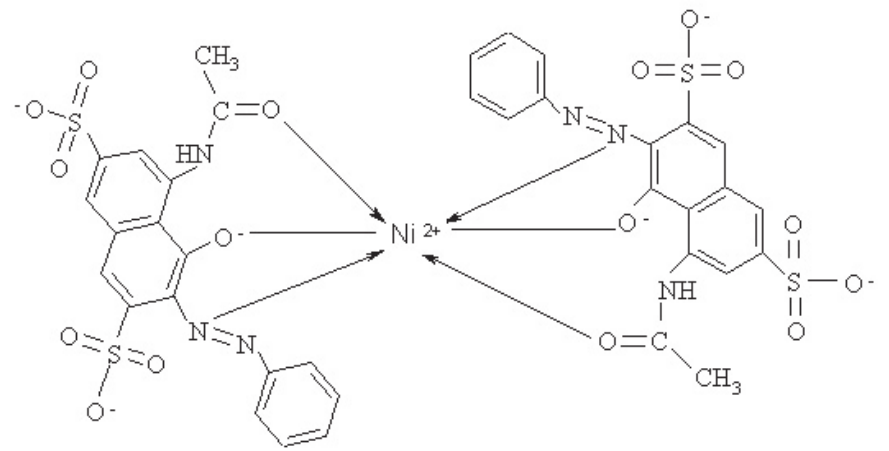

Scheme 2. The proposed structure of the $\mathrm{Ni}(\mathrm{II})(\mathrm{AR} 1)_{2}$ complex

\section{AR 1 in the presence of zinc(II) ions}

The square-wave voltammogram of $4.76 \times 10^{-5} \mathrm{M} \mathrm{Zn}$ (II) ions in $\mathrm{NH}_{3} /$ $\mathrm{NH}_{4} \mathrm{Cl}$ buffer solution $\mathrm{pH} 9.20$ exhibited only one cathodic peak at $-1.184 \mathrm{~V}$ (Fig. 7). In the literature ${ }^{20}$, it was indicated that $\left[\mathrm{Zn}\left(\mathrm{NH}_{3}\right)_{\mathrm{x}}\right]^{2+}$ reduced at halfwave potential of $-1.33 \mathrm{~V}$ (versus satured calomel electrode) with a cathodic peak of two-electrons $(2 \rightarrow 0)$. So, the peak at $-1.184 \mathrm{~V}$ can be sourced from 
the reduction of $\left[\mathrm{Zn}\left(\mathrm{NH}_{3}\right)_{\mathrm{x}}\right]^{2+}$ ions to the amalgam $\left(\mathrm{Zn}(\mathrm{II})+2 \mathrm{e}^{-}\right.$ $\mathrm{Zn}(\mathrm{Hg})$ ). After adding AR 1 into the cell containing $4.76 \times 10^{-5} \mathrm{M} \mathrm{Zn}(\mathrm{II})$, a new peak was no observed except for the $\left[\mathrm{Zn}\left(\mathrm{NH}_{3}\right)_{\mathrm{x}}\right]^{2+}$ and AR 1 . With increasing AR 1 concentration, the peak current of $\left[\mathrm{Zn}\left(\mathrm{NH}_{3}\right)_{x}\right]^{2+}$ decreases (Fig. 8) but its peak potential remains practically unchanged, which verifies the inert character of $\mathrm{Zn}(\mathrm{II})-\mathrm{AR} 1$ complex under the experimental conditions employed. The similar results were obtained for the $\mathrm{Zn}(\mathrm{II})$-nitrilotriacetic acid (NTA) ${ }^{35}$ and $\mathrm{Zn}(\mathrm{II})$-cysteine ${ }^{11}$ systems.

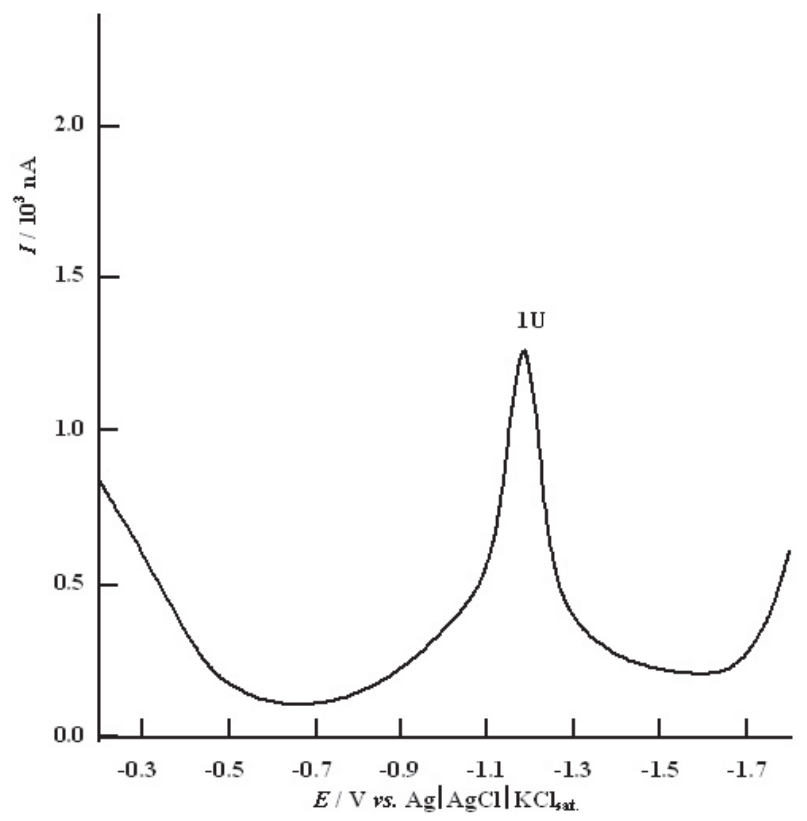

Fig. 7. Square-wave voltammogram of $4.76 \times 10^{-5} \mathrm{M} \mathrm{Zn}$ (II) solution at $\mathrm{NH}_{3} / \mathrm{NH}_{4} \mathrm{Cl}$ buffer solution $\mathrm{pH} 9.20$. 1U, the reduction of free $\mathrm{Zn}(\mathrm{II})$. Other conditions as in Fig. 1.

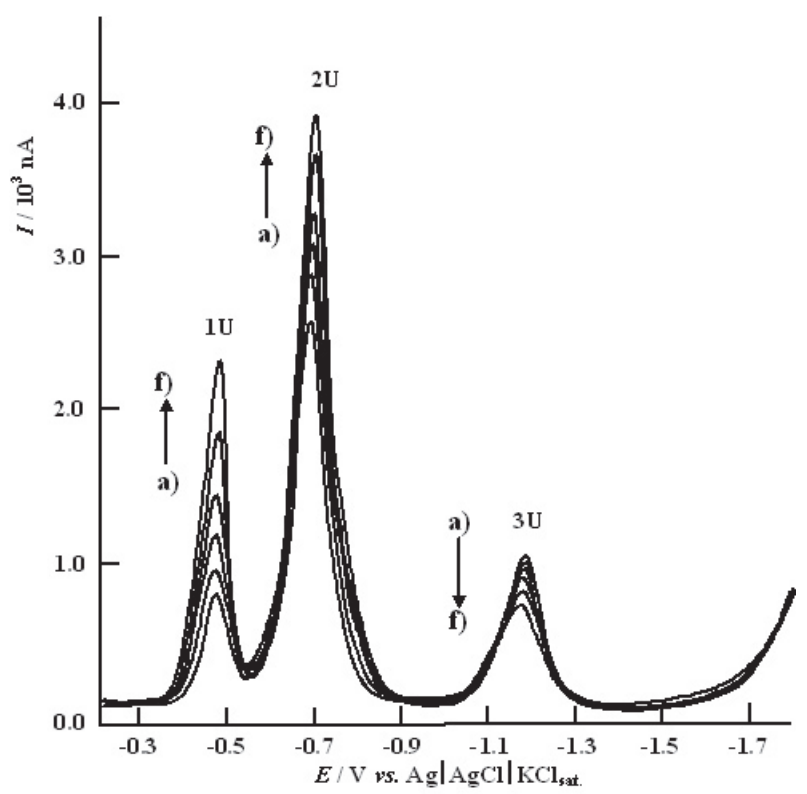

Fig. 8. Square-wave voltammograms of $4.76 \times 10^{-5} \mathrm{M} \mathrm{Zn}$ (II) solution containing a) $1.87 \times 10^{-5} \mathrm{M}$; b) $2.77 \times 10^{-5} \mathrm{M}$; c) $3.67 \times 10^{-5} \mathrm{M}$; d) $4.54 \times 10^{-5} \mathrm{M}$; e) $6.25 \times 10^{-5} \mathrm{M}$; f) $7.90 \times 10^{-5} \mathrm{M}$ AR 1 solution at $\mathrm{NH}_{3} / \mathrm{NH}_{4} \mathrm{Cl}$ buffer solution $\mathrm{pH}$ 9.20. $\mathbf{1} \mathbf{U}$, the adsorption peak of $A R ; \mathbf{2} \mathbf{U}$, the reduction of $-\mathrm{N}=\mathrm{N}$ - group of $\mathrm{AR}$ $1 ; 3 \mathbf{U}$, the reduction of free $\mathrm{Zn}$ (II). Other conditions as in Fig. 1 $\mathbf{1 U}$, the adsorption peak of AR $1 ; \mathbf{2} \mathbf{U}$, the reduction of $-\mathrm{N}=\mathrm{N}-$ group of AR 1; $\mathbf{3} \mathbf{U}$, the reduction of free $\mathrm{Zn}(\mathrm{II})$. Other conditions as in Fig. 1.On the other hand, the effect of increasing $\mathrm{Zn}$ (II) concentration at the $4.76 \times 10^{-5} \mathrm{M}$ AR 1 solution is shown in Fig. 9. With increasing $\mathrm{Zn}(\mathrm{II})$ concentration, the peak currents of free AR 1 decrease while the current of free $\mathrm{Zn}$ (II) peak increases regularly. Apart from those of the free dye and free zinc(II), the additional peaks were not obtained. However, in the excess $\mathrm{Zn}$ (II) concentration, the shape of peak, belongs to the reduction of $-\mathrm{N}=\mathrm{N}-$ group at $-0.676 \mathrm{~V}$, changed and a very poor shoulder formed in the more negative potential range of the reduction of $-\mathrm{N}=\mathrm{N}-$ group. The peaks of AR 1 are not completely suppressed, even at high zinc concentration. This shoulder was also verified to the complex formation between $\mathrm{Zn}(\mathrm{II})$ and $\mathrm{AR} 1$.

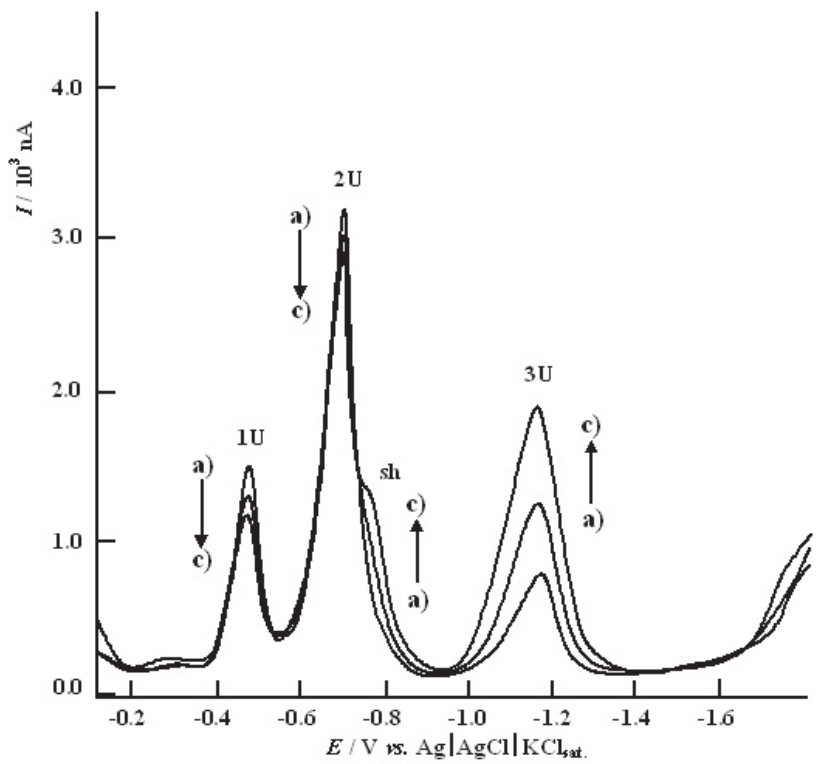

Fig. 9. Square-wave voltammograms of $4.76 \times 10^{-5} \mathrm{M}$ AR 1 solution containing a) $4.54 \times 10^{-5} \mathrm{M}$; b) $8.70 \times 10^{-5} \mathrm{M}$; c) $1.60 \times 10^{-4} \mathrm{M} \mathrm{Zn}$ (II) solution at $\mathrm{NH}_{3} / \mathrm{NH}_{4} \mathrm{Cl}$ buffer solution $\mathrm{pH} 9.20 . \mathbf{1} \mathbf{U}$, the adsorption peak of $\mathrm{AR} 1 ; \mathbf{2} \mathbf{U}$, the reduction of $-\mathrm{N}=\mathrm{N}-$ group of $\mathrm{AR} 1$; $\mathbf{s h}$ (shoulder), the interaction between $\mathrm{Zn}(\mathrm{II})$ and $\mathrm{AR} 1 ; \mathbf{3} \mathbf{U}$, the reduction of free $\mathrm{Zn}(\mathrm{II})$. Other conditions as in Fig. 1 .

In aqueous solution, sample $\mathrm{Zn}$ (II) cations are actually hydrated species (e.g. $\left.\left.\mathrm{Zn}\left(\mathrm{H}_{2} \mathrm{O}\right)_{4}\right]^{2+}\right)$. Treatment of such aqueous species with solutions containing appropriate monodentate ligands such as $\mathrm{NH}_{3}$ can cause displacement of water molecules by the ammonia ligands ${ }^{36}$ :

$$
\left[\mathrm{Zn}\left(\mathrm{H}_{2} \mathrm{O}\right)_{4}\right]^{2+}+4 \mathrm{NH}_{3} \rightleftarrows\left[\mathrm{Zn}\left(\mathrm{NH}_{3}\right)_{4}\right]^{2+}+4 \mathrm{H}_{2} \mathrm{O}
$$

For an inert complex of $\mathrm{Zn}(\mathrm{II})$ with $\mathrm{AR} 1$ in $\mathrm{NH}_{3} / \mathrm{NH}_{4} \mathrm{Cl}$ buffer solution $\mathrm{pH}$ 9.20, electrochemical process can be given in two steps:

$$
\begin{aligned}
& \mathrm{Zn}(\mathrm{II})-\mathrm{AR} 1+\mathrm{xNH}_{3} \rightleftarrows\left[\mathrm{Zn}\left(\mathrm{NH}_{3}\right)_{\mathrm{x}}\right]^{2+}+\mathrm{AR} 1 \\
& {\left[\mathrm{Zn}\left(\mathrm{NH}_{3}\right)_{\mathrm{x}}\right]^{2+}+2 \mathrm{e}^{-} \rightleftarrows \mathrm{Zn}(\mathrm{Hg})+\mathrm{xNH}_{3} \text { at }-1.184 \mathrm{~V}}
\end{aligned}
$$

As a similar manner to the complexation of $\mathrm{Zn}$ (II) with $\mathrm{NTA}^{35}$, the fitting of the experimental data to the following equation for inert complexation,

$$
\left(I_{0}-I\right) / I=[\mathrm{Zn}(\mathrm{II})-\mathrm{AR} 1] /[\mathrm{Zn}(\mathrm{II})]=\beta_{1: 1}[\mathrm{AR} 1]
$$

deduced from the fact that the peak current is proportional to the free metal ion concentration ${ }^{37}$, where $\beta_{\text {, stands for the conditional stability constant under }}$ the experimental condition of this work, [AR 1] is the conditional concentration of the ligand, $I$ and $I_{0}$ are the peak currents of $\mathrm{Zn}$ (II) in the presence and absence of AR 1, respectively. For 1:1 complex, equation (5) is obtained by taking into account that $\Delta E$ is almost zero in the zero order Leden function $F_{0}$.

According to Eq. 5, $I_{0}$ and different values of $I$ are determined respectively by holding the concentration of $\mathrm{Zn}$ (II) constant and varying the concentration of AR 1. The curve of $\left(I_{0}-I\right) / I$ versus [AR 1] (Fig. 10) for Zn-AR 1 complex was plotted and one straight line was obtained. From the slope, the logarithm 
of conditional stability constant was determined as 3.46. It must be pointed out that it was only possible to observe the 1:1 complex at $\mathrm{NH}_{3} / \mathrm{NH}_{4} \mathrm{Cl}$ buffer solution $(\mathrm{pH}=9.20)$.

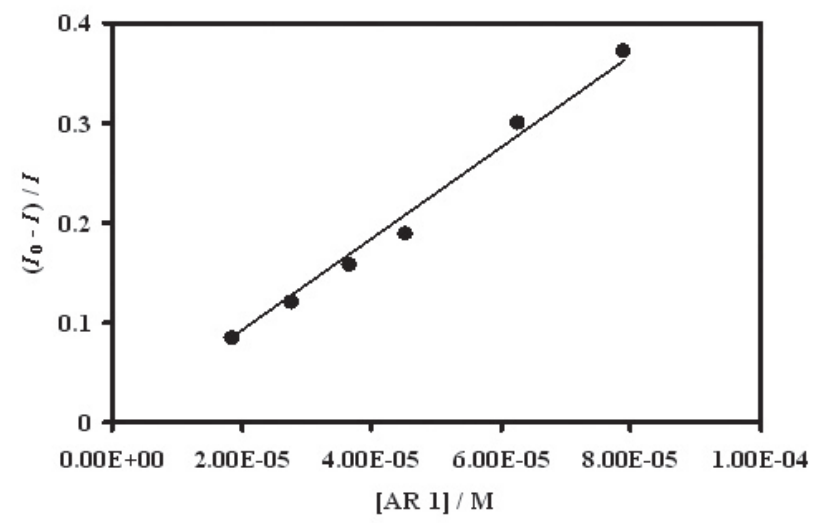

Fig. 10. The plot of $\left(I_{0}-I\right) / I$ versus [AR 1] at $\mathrm{NH}_{3} / \mathrm{NH}_{4} \mathrm{Cl}$ buffer solution pH 9.20 .

At a similar manner to the binding of $\mathrm{Zn}(\mathrm{II})$ ions with some azocompounds $^{34}$, the coordination of AR 1 to $\mathrm{Zn}(\mathrm{II})$ ions may occur mainly by means of its azo-nitrogen and phenolic oxygen. Treatment of $\left[\mathrm{Zn}\left(\mathrm{NH}_{3}\right)_{x}\right]^{2+}$ species with AR 1 may cause displacement of ammonia molecule by AR 1 (Scheme 3).

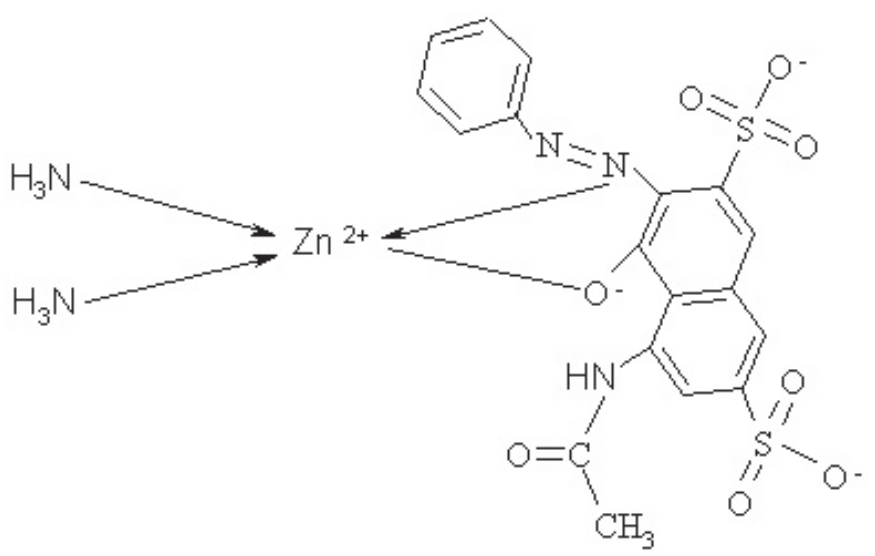

Scheme 3. The possible structure of Zn(II)-AR 1 complex.

\section{Spectroscopic measurements}

In order to get information about the complexation of $\mathrm{AR} 1$ with $\mathrm{Ni}(\mathrm{II})$ and $\mathrm{Zn}(\mathrm{II})$ ions, the electronic spectra studies were also carried out (Figs. 11, 12). The absorption maxima of $\mathrm{AR} 1$ and its $\mathrm{Zn}(\mathrm{II})$ and $\mathrm{Ni}(\mathrm{II})$ complexes are shown in Table 1. According to previous studies ${ }^{36,38}$, the assignments for absorption maxima were made (Table 1). In the literature, the main adsorption band of AR 1 was characterized by peaks at 506 and $531 \mathrm{~nm}^{39}$. AR 1 has strong doublet absorption bands in the visible region. The overlapped double peak can be attributed to the azo and hydrazone tautomeric equilibrium ${ }^{40}$. The double peak at 506 and $530 \mathrm{~nm}$ is the characteristic band of the conjugated electron structure (chromophore group) of this dye $\mathrm{e}^{41}$. It can be also noted that the maximum absorption wavelength of hydrazone form is higher than that of azo form ${ }^{40}$.

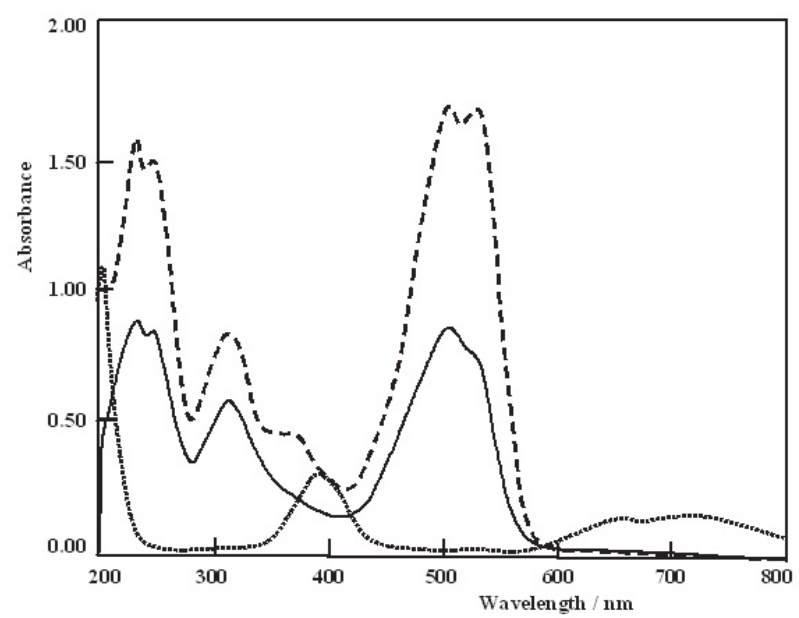

Fig. 11. UV-VIS absorption spectra of $1 \times 10^{-4} \mathrm{M}$ AR 1 (broken line), $1 \times 10$ ${ }^{4} \mathrm{M}$ Ni(II) (dotted line), and $7 \times 10^{-5} \mathrm{M}$ AR 1 solution with $3 \times 10^{-5} \mathrm{M} \mathrm{Ni}$ (II) (solid line) in $\mathrm{NH}_{3} / \mathrm{NH}_{4} \mathrm{Cl}$ buffer (pH 9.20) medium".

Table 1. The electronic spectral data $\left(\lambda_{\text {ax }}\right)$ and their assignments for AR 1 , $\left[\mathrm{Ni}\left(\mathrm{NH}_{3}\right)_{6}\right]^{2+}, \mathrm{Ni}(\mathrm{II})(\mathrm{AR} 1)_{2}$ and $\mathrm{Zn}(\mathrm{II})-\mathrm{AR} 1$ complexes in $\mathrm{NH}_{3} / \mathrm{NH}_{4} \mathrm{Cl}$ buffer (pH 9.20) medium.

\begin{tabular}{|c|c|c|}
\hline Compound & $\lambda_{\max } / \mathbf{n m}$ & Assignment \\
\hline AR 1 & $\begin{array}{l}235 \\
248 \\
313 \\
506 \\
530\end{array}$ & $\begin{array}{c}\qquad \pi \rightarrow \pi^{*} \\
\pi \rightarrow \pi^{*} \\
\text { intramol. CT band } \\
\text { intramol. CT band } \\
\text { intramol. CT band }\end{array}$ \\
\hline$\left[\mathrm{Ni}\left(\mathrm{NH}_{3}\right)_{6}\right]^{2+}$ & $\begin{array}{l}396 \\
656 \\
719\end{array}$ & $\begin{array}{l}{ }^{3} \mathrm{~A}_{2 \mathrm{~g}} \rightarrow{ }^{3} \mathrm{~T}_{1 \mathrm{~g}}(\mathrm{P}) \\
{ }^{3} \mathrm{~A}_{2 \mathrm{~g}} \rightarrow{ }^{3} \mathrm{~T}_{1 \mathrm{~g}}(\mathrm{~F}) \\
{ }^{3} \mathrm{~A}_{2 \mathrm{~g}} \rightarrow{ }^{3} \mathrm{~T}_{1 \mathrm{~g}}(\mathrm{~F})\end{array}$ \\
\hline $\mathrm{Ni}(\mathrm{II})(\mathrm{AR} 1)_{2}$ complex & $\begin{array}{l}234 \\
249 \\
313 \\
505\end{array}$ & $\begin{array}{c}\qquad \rightarrow \pi^{*} \\
\pi \rightarrow \pi^{*} \\
\text { intramol. CT band } \\
\text { intramol. CT band }\end{array}$ \\
\hline $\mathrm{Zn}(\mathrm{II})-\mathrm{AR} 1$ complex & $\begin{array}{l}207 \\
234 \\
257 \\
313 \\
505 \\
531\end{array}$ & $\begin{array}{c}\qquad \rightarrow \pi^{*} \\
\pi \rightarrow \pi^{*} \\
\pi \rightarrow \pi^{*} \\
\text { intramol. CT band } \\
\text { intramol. CT band } \\
\text { intramol. CT band }\end{array}$ \\
\hline
\end{tabular}

In the absorption spectra of the $\mathrm{Ni}\left(\mathrm{H}_{2} \mathrm{O}\right)_{6}{ }^{2+}$, two main bands in the visible region were observed at 14000 and $25000 \mathrm{~cm}^{-1}$ (for the ${ }^{3} \mathrm{~A}_{2 \mathrm{~s}} \rightarrow{ }^{3} \mathrm{~T}$ (F) and ${ }^{3} \mathrm{~A}_{2 \mathrm{~g}} \rightarrow{ }^{3} \mathrm{~T}_{\mathrm{lg}}(\mathrm{P})$, respectively) ${ }^{36}$. As can be seen in Table 1 , $\left[{ }^{2} \mathrm{Ni}\left(\mathrm{NH}_{3}\right)_{6}\right]^{2+}$ has two bands at 396 and 656-719 $\mathrm{nm}$ (the splited band) in the visible region higher frequencies than the corresponding $\mathrm{Ni}\left(\mathrm{H}_{2} \mathrm{O}\right)_{6}{ }^{2+}$ bands $^{36}$, as a similar manner to $\mathrm{Ni}(\mathrm{en})_{3}{ }^{2+}$ complex ions ${ }^{36}$. Ligand-to-metal charge transfer bands are often prominent in the spectra of complexes in which there are electrons in $\pi$ orbitals of the ligands, and the absorption bands largely obscure the weaker $d-d$ transitions ${ }^{36}$. Therefore, in the spectrum of $\mathrm{Ni}$ (II)(AR 1) complex, the $d-d$ transitions were not observed. As is known, the absorption bands in the visible region of the metal-azo complex do not arise from the forbidden $d-d$ transitions of the metal itself, for these are too weak ${ }^{34}$. They are assigned to the allowed intense $\pi \rightarrow \pi^{*}$ transitions of the azo chromophore ${ }^{34}$. Metal substitution may lead to mixing between the $\pi$ systems of the azo ligands via interaction of metal-ion $d$ and azo $\pi$ orbitals to form an extended $\pi$ systems $^{34}$. In the spectra of AR 1 solutions containing $\mathrm{Ni}(\mathrm{II})$ ions, the absorption bands of AR 1 were slightly shifted and also the relative intensity of the band at $530 \mathrm{~nm}$ considerably decreased according to that of band at $506 \mathrm{~nm}$, confirming the coordination of AR 1 with $\mathrm{Ni}(\mathrm{II})$ ions. Moreover, the formation of strong metal-ligand 
coordinate covalent bonds causes a shift of the tautomeric equilibrium towards the azo form.

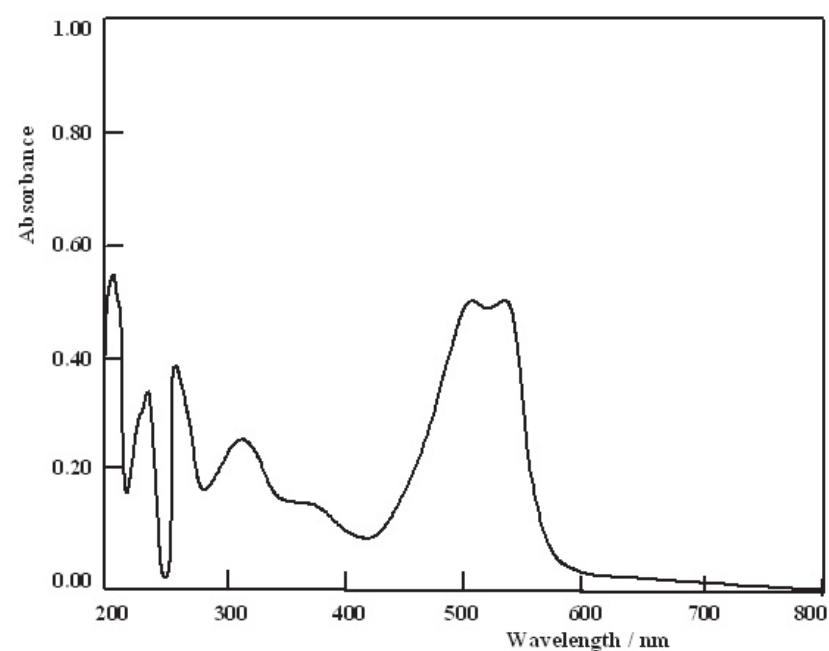

Fig. 12. UV-VIS absorption spectrum of $5 \times 10^{-5} \mathrm{M}$ AR 1 solution with $5 \times 10^{-5} \mathrm{M} \mathrm{Zn}$ (II) in $\mathrm{NH}_{3} / \mathrm{NH}_{4} \mathrm{Cl}$ buffer ( $\mathrm{pH} 9.20$ ) medium.

Zn(II)-AR 1 complex does not show any $d$ - $d$ transitions but displays charge transfer bands at 313,505 and $531 \mathrm{~nm}$, respectively. Also, in the spectra of AR 1 solutions containing $\mathrm{Zn}$ (II) ions, the absorption bands of AR 1 were slightly shifted towards lower and/or higher frequencies. We attribute these shifts to formation of a weak $\mathrm{Zn}$ (II)-AR 1 complex maintaining the conjugated electron structure of AR 1 molecule.

\section{CONCLUSION}

In this study, the interaction of $\mathrm{AR} 1$ with $\mathrm{Zn}(\mathrm{II})$ and $\mathrm{Ni}(\mathrm{II})$ ions was reported. The overall stability constants and stoichiometries and also possible mechanisms of $\mathrm{Zn}(\mathrm{II})-\mathrm{AR} 1$ and $\mathrm{Ni}(\mathrm{II})-\mathrm{AR} 1$ interactions were determined successfully by using the simple and rapid voltammetric procedure. Finally, the strength of $\mathrm{Ni}(\mathrm{II})$ binding to AR 1 is more than that of $\mathrm{Zn}(\mathrm{II})$.

\section{REFERENCES}

1. O. Abollino, C. Sarzanini, E. Mentasti and A. Liberatori, Talanta, 41, 1107 (1994).

2. S. Wang, S. Shen and H. Xu, Dyes Pigments 44, 195 (2000).

3. Chapman D.D., Goswami R, Kovacs CA, European Patent Application EP 0649884, 1995.

4. H. Park, E-R. Kim, D.J. Kim, H. Lee, Bull. Chem. Soc. Jpn. 75, 2067 (2002)

5. O. Çakır, E. Biçer, Electroanal. 9, 87, (1997).

6. S. Cakır, E. Biçer, A. Eleman, Transit. Metal Chem. 26, 89, (2001).

7. O. Çakır, E. Coşkun, E. Biçer, S. Çakır, Turk. J. Chem. 25, 33, (2001).

8. S. Çakır, İ. Bulut, E. Biçer, E. Coşkun, O. Çakır, J. Electroanal. Chem. 511, 94, (2001).

9. S. Çakır, E. Coşkun, E. Biçer, O. Çakır, Carbohyd. Res. 338, 1217, (2003).

10. S. Çakır, İ. Bulut, E. Biçer, O. Çakır, J. Coord. Chem. 56, 511, (2003).

11. E. Biçer, E. Cinar, J. Coord. Chem. 58, 775, (2005).

12. T. M. Florence, W.L. Belew, J. Electroanal. Chem. 21, 157, (1969).

13. A.Z. Abu Zuhri, Anal. Lett. 19, 345, (1986).

14. L. Dubenska, H. Levytska, N. Poperechna, Talanta 54, 221, (2001).

15. M. Gawrys, J. Golimowski, Electroanal. 15, 1017, (2003).

16. K. Y. El-Baradie, Monatsh. Chem. 136, 677, (2005).

17. M. K. Amini, M. Kabiri, J. Iran. Chem. Soc. 2, 32, (2005).

18. http://www.free-medical-dictionary.net/azophloxin.html

19. M. Mrowetz, E. Selli, Phys. Chem. Chem. Phys. 7, 1100, (2005).

20. J. Heyrovský, J. Kůta, Principles of Polarography, Academic Press, New York, 1966, p. 541, 547.

21. E. Bicer, C. Arat, Croat. Chem. Acta, in the press.
22. D.R. Crow, Polarography of Metal Complexes, Academic Press, London, 1969, p.57, 9 .

23. J. Urbanska, H. Kozlowski, J. Coord. Chem. 42, 197, (1997).

24. D.R. Crow, M. Rose, Electrochim. Acta 24, 41, (1979).

25. P.K. Aggarwal, D.R. Crow, Electrochim. Acta 25, 411, (1980).

26. J. Urbanska, Electrochim. Acta 30, 261, (1985).

27. J. Urbanska, H. Kozlowski, A. Delannoy, J. Hennion, Anal. Chim. Acta 207, 85, (1988).

28. J. Urbanska, H. Kozlowski, J. Coord. Chem. 21, 175, (1990).

29. N. Youyou, P. Decock, D. Blondeau, J. Urbanska, H. Kozlowski, J. Coord. Chem. 30, 283, (1993).

30. K. Morinaga, B. Chem. Soc. Jpn. 29, 793, (1956).

31. N.Q. Li, J. Min, Chinese J. Anal. Chem. (FenXiHuaXue) 17, 346, (1989).

32. J. Rydberg, Acta Chem. Scand. 15, 1723 (1961).

33. K.B. Gudasi, S.A. Patil, R.S. Vadavi, R.V. Shenoy, M.S. Patil, J. Serb. Chem. Soc. 71, 529, (2006).

34. W. Bin, W. Yi-Qun, G. Dong-Hong, G. Fu-Xi, Chinese Phys. Lett. 20 , 1596, (2003).

35. F. Berbel, J.M. Diaz-Cruz, C. Arino, M. Esteban, J. Electroanal. Chem. 453, 151, (1998).

36. W.L. Jolly, Modern Inorganic Chemistry, McGraw-Hill Book Company, New York, 1985, p. 342, 411, 414, 417.

37. J. Buffle, Complexation Reactions in Aquatic Systems: An Analytical Approach, Ellis Horwood, Chichester, 1989.

38. M.A. El-Taher, M.T. El-Haty, A.A. Montaser, Microchim. Acta 129,133, (1998).

39. M.R. Massafra, E. Selli, S. Salsa, B. Marcandalli, Dyes Pigments 40, 171, (1999).

40. St. Stoyanov, L. Antonov, Dyes Pigments 10,33, (1988).

41 Cs.M. Földváry, L. Wojnárovits, Radiat. Phys. Chem. 76, 1485, (2007). 